\title{
Stability of a Lipase Extracted from Seeds of Pachira aquatica in Commercial Detergents and Application Tests in Poultry Wastewater Pretreatment and Fat Particle Hydrolysis
}

\author{
Patrícia Peres Polizelli, Fernanda Dell Antonio Facchini, \\ and Gustavo Orlando Bonilla-Rodriguez \\ Department of Chemistry and Environmental Sciences, IBILCE-UNESP, State University of São Paulo, \\ Rua Cristóvão Colombo 2265, 15054-000 São José do Rio Preto, SP, Brazil
}

Correspondence should be addressed to Gustavo Orlando Bonilla-Rodriguez; rbog2010@gmail.com

Received 13 September 2013; Revised 25 November 2013; Accepted 25 November 2013

Academic Editor: Giovanni Gadda

Copyright (C) 2013 Patrícia Peres Polizelli et al. This is an open access article distributed under the Creative Commons Attribution License, which permits unrestricted use, distribution, and reproduction in any medium, provided the original work is properly cited.

\begin{abstract}
A protein extract containing a plant lipase from oleaginous seeds of Pachira aquatica was tested using soybean oil, wastewater from a poultry processing plant, and beef fat particles as substrate. The hydrolysis experiments were carried out at a temperature of $40^{\circ} \mathrm{C}$, an incubation time of 90 minutes, and $\mathrm{pH}$ 8.0-9.0. The enzyme had the best stability at $\mathrm{pH} 9.0$ and showed good stability in the alkaline range. It was found that $P$. aquatica lipase was stable in the presence of some commercial laundry detergent formulations, and it retained full activity up to $0.35 \%$ in hydrogen peroxide, despite losing activity at higher concentrations. Concerning wastewater, the lipase increased free fatty acids release by 7.4 times and promoted the hydrolysis of approximately $10 \%$ of the fats, suggesting that it could be included in a pretreatment stage, especially for vegetable oil degradation.
\end{abstract}

\section{Introduction}

Lipases (triacylglycerol lipases, E.C. 3.1.1.3) are enzymes that catalyze the cleavage of carboxyl ester bonds present in acylglycerols with the subsequent release of fatty acids and glycerol. They are particularly important because they specifically hydrolyze oils and fats, an interesting ability for different industrial applications [1]. These enzymes have become more and more prominent on the enzyme biotechnology scenario due to their versatility for hydrolysis and synthesis and for their catalytic reactions often being chemoselective, regionselective, or enantioselective [2].

Lipases can be obtained from animals (pancreatic, hepatic, and gastric sources), microorganisms (bacterial, fungal, and yeast), or plants, with variations in their catalytic properties [3]. Nevertheless, recently, seed lipases have been the focus of increasing attention as biocatalysts. In some cases, these enzymes present advantages over animal and microbial lipases due to some very interesting features such as specificity, low cost, availability, and easily purification, representing a great alternative for potential commercial use as industrial enzymes [4-6].

The participation of lipases in the worldwide enzyme industry market has grown significantly and it includes a wide range of applications in many sectors such as food, pharmaceutical, fine chemical, oil chemical, and detergent industries as well as in biodiesel and wastewater treatment [7-9]. One interesting application of lipases is their use in oil chemical industries, reducing energy expenses and minimizing heat degradation of compounds in comparison to traditional chemical processes [7]. Another potential application is in wastewater treatment where several aerobic and anaerobic processes are used. However, it is necessary to reduce fats (which in high concentration can cause sludge flotation and/or the development of sludge with different physical characteristics and/or poor activity), oil, and protein 
concentration in order to enable biological treatment to proceed without any inhibition during the reduction of organic matter in wastewater [10-12]. The previous researchers suggested that the lipase application in pretreatment to partially hydrolyze fat particles could accelerate the anaerobic treatment of slaughterhouse wastewater and several research studies have been done on the treatment of oily wastes using lipases [13-18].

In waste treatment, the use of low-cost enzymatic preparations is vital, since the use of high-cost commercial enzymatic preparations would make the pretreatment procedure not feasible [11].

The characteristics displayed by lipases have accounted for a marked increase in their industrial use over the last two decades. However, their single biggest market is detergent formulations. The functional importance of lipases in detergent industries is to remove fatty residues in laundry and dishwashers, for cleaning clogged drains, and for avoiding pipes' clogging [4, 19-21]. Some studies have been done adding lipases to detergent formulations or adding these detergents to lipase assays to evaluate enzyme stability [4, 9, 20]. A variety of detergents were evaluated for their efficiency in removing olive oil from cotton fabrics with and without lipase; removal was higher (7-12\%) in the presence of a lipase for all the tested detergents [20]. Similar results were reported for lipases from Ralstonia pickettii [22].

The application of a pretreatment process to hydrolyze and dissolve fats may improve the biological degradation of fatty wastewater, accelerating the process by decreasing the fat adsorption to the surface of the anaerobic sludge and not limiting the transport of the soluble substrate to the biomass $[10,23]$. Beef fat particles represent a regional environmental concern due to the large number of slaughterhouses located in the State of São Paulo and nearby. Beef fat was chosen in this work because it demonstrated better results than pork fat as described by Masse et al. [13] possibly due to its different fatty acid composition.

The present work reports the effects and the characterization of a plant lipase extracted from $P$. aquatica, able to hydrolyze soybean oil and fats from poultry wastewater as well as its stability under different commercial detergents.

\section{Materials and Methods}

2.1. Enzyme Extraction. The seeds were collected from Pachira aquatica trees at UNESP (São Paulo State University), in São José do Rio Preto, SP, Brazil. The oilseeds were washed, peeled, and extracted by homogenization in a food processor with a solution described by Polizelli et al. [4], containing $3 \mathrm{mM}$ DTT (dithiothreitol), $1 \mathrm{mM}$ EDTA, $10 \mathrm{mM}$ sodium metabisulfite, and $50 \mathrm{mM}$ Tris buffer $\left(\mathrm{pH} \mathrm{8.0)}\right.$ ) at $25^{\circ} \mathrm{C}$. The samples were clarified by centrifugation at $9,000 \times \mathrm{g}$ for $40 \mathrm{~min}$, at $4^{\circ} \mathrm{C}$ using a Jouan CR3i refrigerated centrifuge, $\left(4^{\circ} \mathrm{C}\right)$ and the supernatant was concentrated and stored in a freezer (Thermo Scientific) at $-80^{\circ} \mathrm{C}$. The Tris buffers were prepared at room temperature but their $\mathrm{pH}$ was calculated for the temperature of the assay, using the temperature factor $\Delta \mathrm{pKa} /{ }^{\circ} \mathrm{C}-0.031[24]$.
2.2. Lipase Assay and Protein Determination. The lipolytic activity was measured by titration as already described [4]. Free fatty acids concentration was also determined by a titration method, and a standard curve was prepared with linoleic acid to determine the release of fatty acids during hydrolysis. The reaction solution contained $50 \%$ soybean oil, $31.3 \%$ $30 \mathrm{mM}$ Tris buffer ( $\mathrm{pH} 8.0$ ), 10.15\% Triton X-100, $0.002 \%$ of $10 \mathrm{mM} \mathrm{CaCl}_{2}$, and $9.6 \%$ crude extract. The reaction was stopped by adding acetone: ethanol (1:1), and the released fatty acids were titrated with $50 \mathrm{mMKOH}$ in the presence of phenolphthalein as indicator. Protein concentrations were measured using the dye binding method [25] and using BSA (bovine serum albumin) as a standard protein.

2.3. Lipase Characterization. The influence of $\mathrm{pH}$ varying from 3.0 to 10.0 and temperature from 25 to $60^{\circ} \mathrm{C}$ in lipase activity was evaluated using soybean oil and poultry wastewater as enzymatic substrates. Soybean oil was chosen in this work because it is the cheapest and the most common cooking oil in Brazil, and therefore it contributes to water and soil pollution as a domestic and industrial wastewater. The enzymatic activity was analyzed as described above.

\subsection{Enzymatic Stability in the Presence of Commercial Deter-} gents. The lipase stability was studied in the presence of hydrogen peroxide $(0-20 \%)$ by direct incorporation into the assay mixture, and the stability was tested using several commercial laundry detergents available in the local market. For this experiment three concentrations were used (i.e., 3.3, 6.6, and $10 \mathrm{mg} / \mathrm{mL}$ ) of Ariel and Ace (Procter \& Gamble), Surf and Omo (Unilever), and Tixan (Ypê). Since these detergents contain some enzymes (lipases, proteases, and cellulases, according to the manufacturer), all of them were autoclaved for 30 minutes before being added to the lipase assay, to promote enzyme thermal denaturation. The same experiment was carried out using the best detergent concentration obtained at $40^{\circ} \mathrm{C}$ using soybean oil as substrate, for a period of $4 \mathrm{~h}$. Aliquots were taken every $60 \mathrm{~min}$ in order to perform the enzyme assay and determine the stability.

\subsection{Hydrolysis of Poultry Wastewater and Beef Fat Particles.} Wastewater was collected from a poultry processing industry (Guapiaçu, SP, Brazil). The samples were treated with different enzyme concentrations $(3-20 \mathrm{mg} / \mathrm{mL})$ added to Tris buffer ( $\mathrm{pH} 8.0$ ), in different incubation times (0-200 min), at the lipase optimal temperature and $\mathrm{pH}$ obtained $\left(40^{\circ} \mathrm{C}, \mathrm{pH}\right.$ 8.0).

Fat particles' hydrolysis experiments were conducted as described by Masse et al. [13] with some modifications. Pieces of beef fat were cut as uniform small particles $(5 \mathrm{~mm})$, dried at $30^{\circ} \mathrm{C}$, weighed, and stored at $4^{\circ} \mathrm{C}$. In $50 \mathrm{~mL}$ Erlenmeyer flasks, different concentrations of crude extract $(5,10,15$, and $20 \mathrm{mg} / \mathrm{mL}$ ) and $100 \mathrm{mM}$ Tris buffer $\mathrm{pH} 8.0$ were added to one fat piece and agitated in a shaker at $30 \mathrm{rpm}$, at $40^{\circ} \mathrm{C}$ during 6,12 , and $24 \mathrm{~h}$. The same experiment was repeated with the best enzyme concentration during $72 \mathrm{~h}$ in order to determine the best condition for the hydrolysis. The mixture was then filtered and the remaining particles dried at $30^{\circ} \mathrm{C}$ 


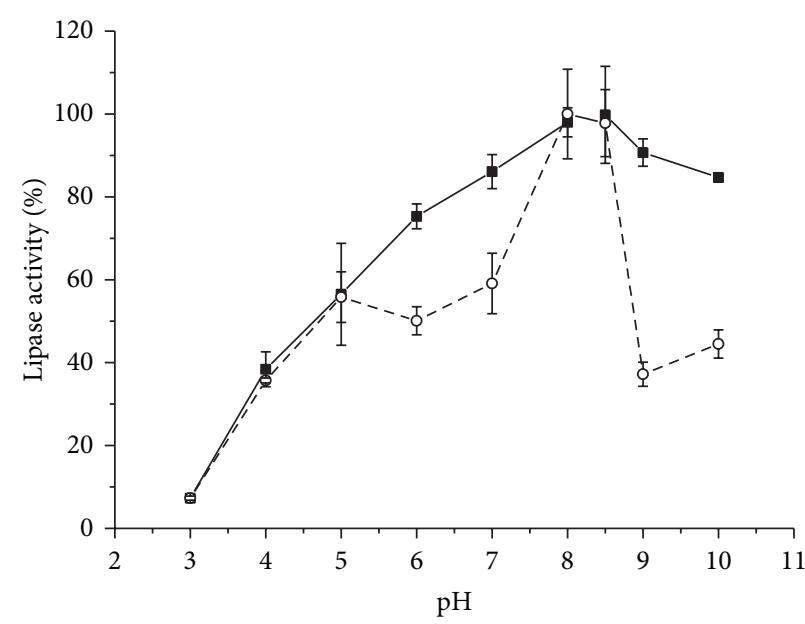

(a)

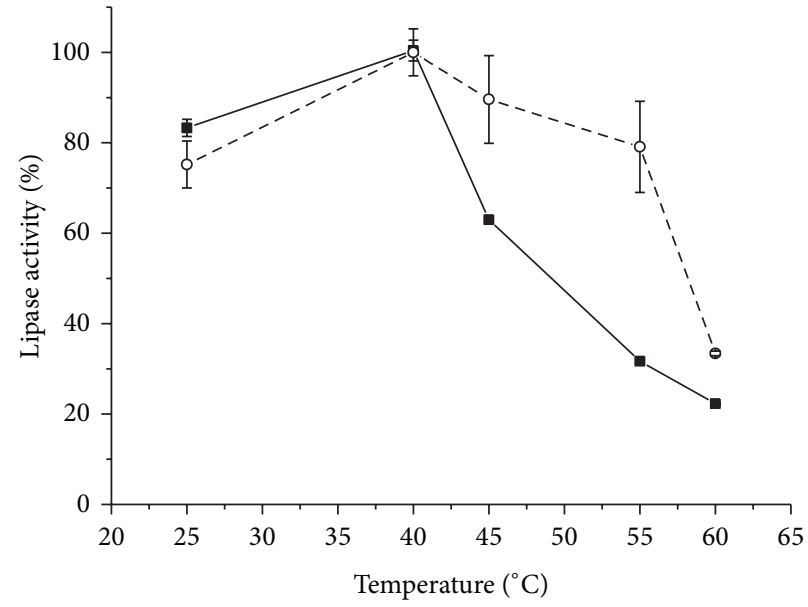

(b)

FIGURE 1: Effect of (a) pH and (b) temperature on P. aquatica lipase activity. Activity was measured by free fatty acids titration using soybean oil (-ח-) and poultry waste water (-o-) as enzyme substrates.

and weighed. Control samples consisted of a beef fat piece with $100 \mathrm{mM}$ Tris buffer $\mathrm{pH} 8.0$ under the same experimental conditions. The average particle mass data obtained during these experiments were analyzed statistically by the Student's $t$-test[26], using the freeware BioEstat 4.0 [27] and $P<0.05$.

\section{Results and Discussion}

3.1. Lipase Characterization. The lipase from P. aquatica showed higher activity in a $\mathrm{pH}$ range of 8.0-9.0 and at $40^{\circ} \mathrm{C}$ (Figures 1(a) and 1(b)) for both substrates during a 90-minute incubation period; afterwards, we observed a decrease of the hydrolysis rate, probably due to the accumulation of free fatty acids that could inhibit the enzyme [28]. Accordingly, this lipase acts at alkaline $\mathrm{pH}$ and mild temperatures, as those used in detergent and leather industries and wastewater treatment $[5,21,22,29]$.

These results were similar to those obtained for the synthetic substrate $p$-nitrophenyl palmitate [4]. The same optimum temperature was reported [30] for a lipase from the seeds of Jatropha curcas and an optimal pH of 7.5 using olive oil. The majority of studies with seed lipases indicate a neutral-alkaline optimum $\mathrm{pH}$ and higher activity over a temperature range from 30 to $40^{\circ} \mathrm{C}[2,31]$. However, other authors verified acid seed lipases, for example, castor bean lipase, at optimum $\mathrm{pH}$ values of 4.2 [32]. The optimum temperature around $40^{\circ} \mathrm{C}$ for this study parallels the earlier findings on lipases from coconut seeds [31], Barbados nuts [30], and rapeseeds [33].

\subsection{Effect of Detergents and Oxidizers on Lipase Activity} and Stability. In the presence of hydrogen peroxide the $P$. aquatica lipase showed a biphasic decrease of activity and retained only $30 \%$ of its activity in the presence of $1 \% \mathrm{H}_{2} \mathrm{O}_{2}$ but still displayed $24 \%$ of the original activity at $5 \% \mathrm{H}_{2} \mathrm{O}_{2}$ (Figure 2).

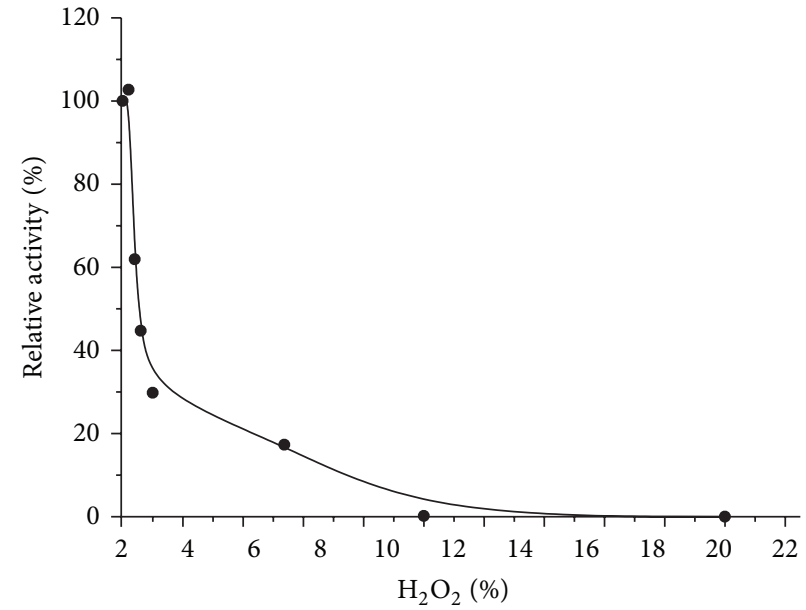

FIgURE 2: $P$. aquatica lipase activity in different concentrations of hydrogen peroxide.

Table 1 shows that the enzyme retained approximately $100 \%$ of its activity in the presence of $3.3 \mathrm{mg} / \mathrm{mL}$ of Tixan, Surf, and Ace and around $80 \%$ using Ariel. Despite the decrease of lipase activity in Ariel and Tixan, the other detergents presented stability higher than $80 \%$ in $6.6 \mathrm{mg} / \mathrm{mL}$. These results are very appropriate in laundry industries, since the concentration generally used in a washing machine is around $7 \mathrm{mg} / \mathrm{mL}$ [34].

Another interesting result is for Omo, which obtained an increase of activity in higher detergent concentrations. Possibly, this detergent formulation could have a compound such as calcium or a tensoactive $[9,34]$ which increases the activity or acts at the interface water-oil, opening the enzyme active site, stabilizing its hydrophobic surface, and facilitating the hydrolysis. [35]. This stability in Omo could be easily observed in Figure 3; $40 \%$ of the lipase activity 


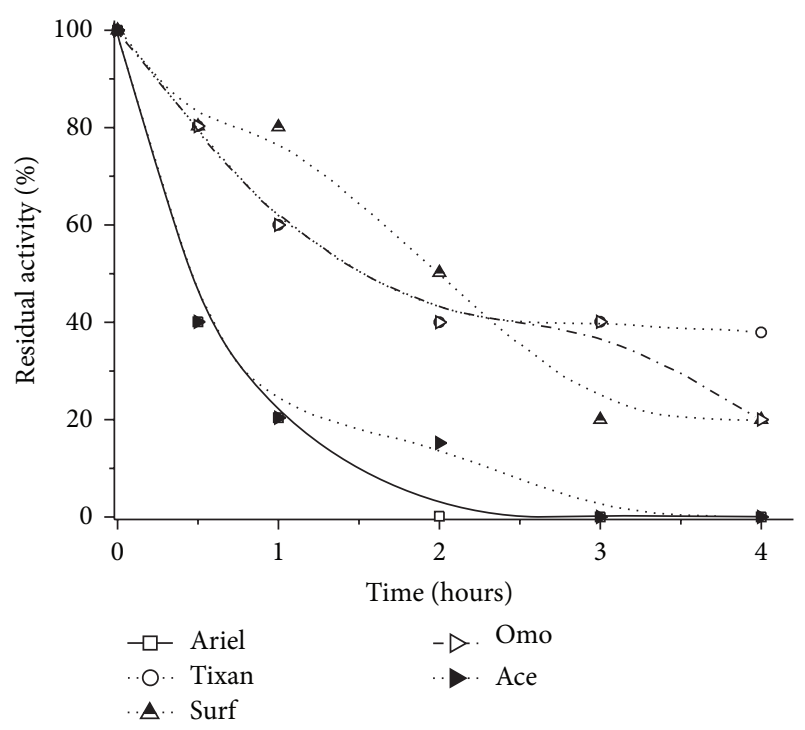

FIgURE 3: P. aquatica lipase stability in different commercial detergents (Ariel and Tixan-3.3 mg/mL; Surf, Ace, and Omo$6.6 \mathrm{mg} / \mathrm{mL})$.

TABLE 1: Relative enzyme activity in the presence of different concentrations of commercial detergents.

\begin{tabular}{lccc}
\hline Detergent & \multicolumn{3}{c}{ Relative activity (\%) } \\
& $3.3 \mathrm{mg} / \mathrm{mL}$ & $6.6 \mathrm{mg} / \mathrm{mL}$ & $10 \mathrm{mg} / \mathrm{mL}$ \\
\hline Ariel & $80.4 \pm 0.1$ & $60.7 \pm 0.0$ & $54.0 \pm 0.1$ \\
Tixan & $100.0 \pm 0.1$ & $60.5 \pm 0.1$ & $60.0 \pm 0.1$ \\
Surf & $100.0 \pm 0.0$ & $100.0 \pm 0.1$ & $80.0 \pm 0.0$ \\
Ace & $100.0 \pm 0.1$ & $100.0 \pm 0.1$ & $80.0 \pm 0.1$ \\
Omo & $60.0 \pm 0.1$ & $80.5 \pm 0.1$ & $80.2 \pm 0.1$ \\
\hline
\end{tabular}

was maintained after $4 \mathrm{~h}$, compared to other detergents that caused a decrease to $0-20 \%$.

This stability can be compared to the behavior displayed by fungal lipases. A lipase from Aspergillus niger showed great stability in the presence of Ariel, Surf Ultra, and Surf Excel (Saisubramanian et al., 2006 [20]), and similar results were reported for lipases from Aspergillus sp. and Rhizopus sp. [36].

3.3. Wastewater Hydrolysis. The concentration of free fatty acids (FFA) in wastewater was analyzed before the lipolytic treatment $(0.23 \pm 0.07 \mathrm{mM})$. Adding $P$. aquatica lipase to the wastewater mixture, the maximum activity was reached with 60 minutes of incubation, releasing $1.7 \pm 0.35 \mathrm{mM}$ FFA. Although this result represents around $10 \%$ of the total esters, it is 7.4 times higher than the concentration of the control samples. Rigo et al. [17] reported that the maximum conversion condition for a lipase from Penicillium restrictum yielded $0.1 \mathrm{mM}$ of free acid/mL using $5.0 \%(\mathrm{w} / \mathrm{v})$ enzyme at $45^{\circ} \mathrm{C}$, in swine meat wastewater. These results are important to industry development since few studies have been published using lipases in fat wastewater. These are important results since the major constituents of animal fats

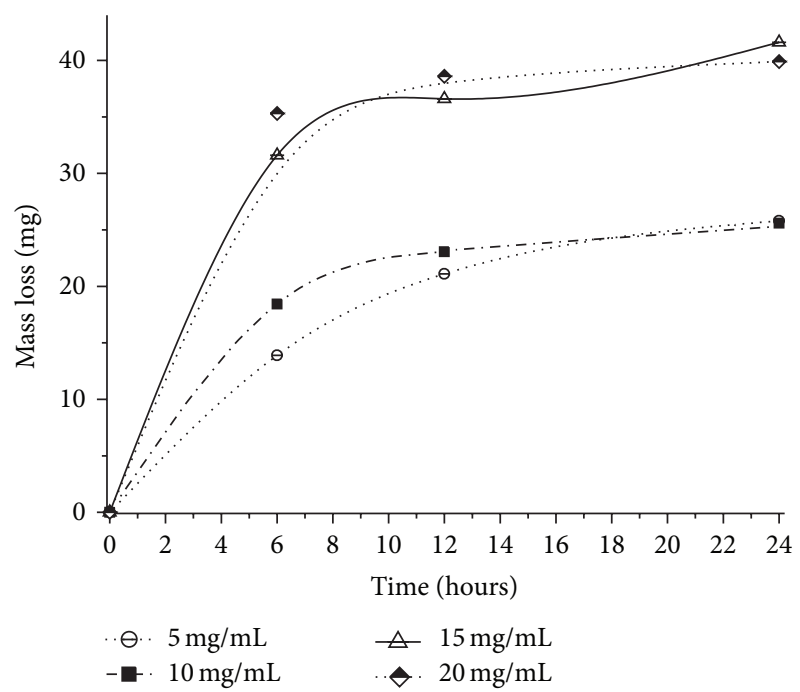

FIGURE 4: Reduction in the average mass of beef fat particles after 24 hours of pretreatment with different lipase concentrations at $40^{\circ} \mathrm{C}$ and $\mathrm{pH}$ 8.0. The initial mass was $300 \mathrm{mg} \pm 0.06$.

are triacylglycerols consisting of saturated and unsaturated fatty acids [37].

A poultry processing plant usually generates large amounts of wastewater, both in the process itself and in the washing of equipments and facilities, well characterized by high organic and suspended solids concentration, mainly fats and protein [12]. However, the characteristics of the wastewater vary among processing plants, depending on the industrial process and the water consumed per slaughtered bird [38].

3.4. Fat Particles' Degradation. Grindstone et al. [39] reported that, in beef, $18.4 \%$ of the triacylglycerols are composed by saturated fatty acids, while $45.1 \%$ have only one unsaturated fatty acid. In a previous study [4] it was verified that the lipase from $P$. aquatica showed higher enzymatic activity with monounsaturated oleic $(18: 1)$ compared to linoleic $(18: 2)$ and linolenic $(18: 3)$ acids. At this point, the effect of the lipase in fat particle degradation was tested using different enzyme concentrations and incubation time (Figures 4 and 5). After 72 hours of lipase hydrolysis, it was observed a $13 \%$ decrease in fat particle mass in solution compared to the original value. Using a higher enzyme dose $(30 \mathrm{mg} / \mathrm{mL})$, a maximum particle mass reduction was obtained $(14.3 \%)$, but these results did not show significant differences when analyzed statistically. Masse et al. [13] reported no significant particle size reduction after $4 \mathrm{~h}$ of pretreatment with the plant lipase EcoSystem Plus, finding a higher effectiveness (a 40\% reduction of fat particle size) using pancreatic lipase PL-250. This difference is higher once pancreatic lipase has much higher activity than plant lipases, but the major disadvantage is the difficulty to extract it. Wild type plant lipases would need a longer hydrolysis time. 


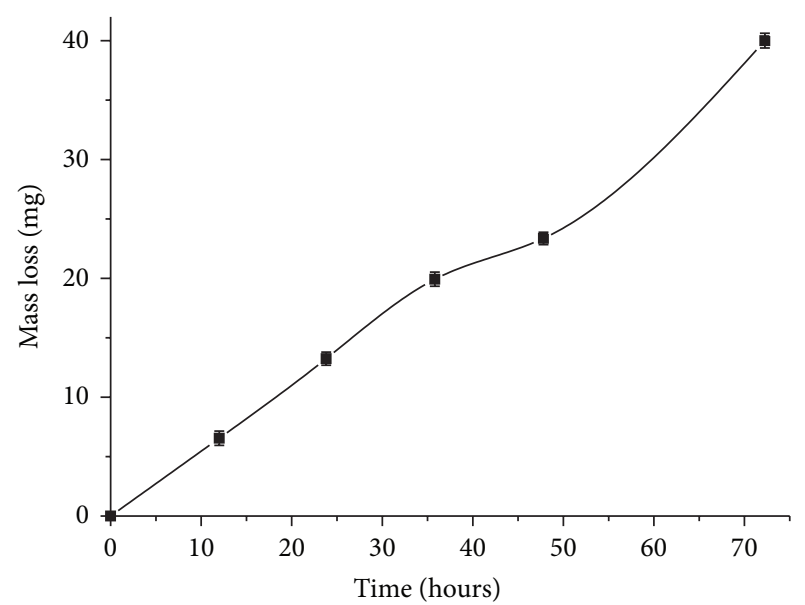

FIGURE 5: Reduction in the average mass of beef fat particles after 72 hours of pretreatment with lipase $(10 \mathrm{mg} / \mathrm{mL})$ at $40^{\circ} \mathrm{C}$ and $\mathrm{pH} 8.0$. The initial mass was $300 \mathrm{mg} \pm 0.06$.

\section{Conclusions}

The results in this work suggest that the crude single lipase from $P$. aquatica could be used for oil and fats wastewater pretreatment and, in future, for wastewater treatment due to its ability to hydrolyze soybean oil and other vegetable oils as shown previously [4]. The results suggest that $P$. aquatica lipase can be more effective for vegetable oil degradation than for animal fats.

\section{Acknowledgments}

This work had financial support from FAPESP, CNPq, and CAPES (Brazil).

\section{References}

[1] M. C. M. R. Leal, M. C. Cammarota, D. M. G. Freire, and G. L. Sant'Anna Jr., "Hydrolytic enzymes as coadjuvants in the anaerobic treatment of dairy wastewaters," Brazilian Journal of Chemical Engineering, vol. 19, no. 2, pp. 175-180, 2002.

[2] M. Barros, L. F. Fleuri, and G. A. Macedo, "Seed lipases: sources, applications and properties-a review," Brazilian Journal of Chemical Engineering, vol. 27, no. 1, pp. 15-29, 2010.

[3] K. D. Mukherjee and M. J. Hills, "Lipases from plants," in Lipases-Their Structure, Biochemistry and Application, P. Woolley and S. B. Petersen, Eds., pp. 49-75, Cambridge University Press, Cambridge, UK, 2002.

[4] P. P. Polizelli, F. D. A. Facchini, H. Cabral, and G. O. BonillaRodriguez, "A new lipase isolated from oleaginous seeds from Pachira aquatica (bombacaceae)," Applied Biochemistry and Biotechnology, vol. 150, no. 3, pp. 233-242, 2008.

[5] F. W. Paques and G. A. Macedo, "Plant lipases from latex: properties and industrial applications," Quimica Nova, vol. 29, no. 1, pp. 93-99, 2006.

[6] V. N. Enujiugha, F. A. Thani, T. M. Sanni, and R. D. Abigor, "Lipase activity in dormant seeds of the African oil bean (Pentaclethra macrophylla Benth)," Food Chemistry, vol. 88, no. 3, pp. 405-410, 2004.
[7] G. D. M. Freire and F. L. Castilho, "Lipases em Biocatálise," in Enzimas em Biotecnologia: Produção, Aplicação e Mercado, E. P. S. Bon, M. A. Ferrara, and M. L. Corvo, Eds., pp. 369-348, Interciência, Rio de Janeiro, Brazil, 2008.

[8] F. O. M. Alonso, E. B. L. Oliveira, G. M. Dellamora-Ortiz, and F. V. Pereira-Meirelles, "Improvement of lipase production at different stirring speeds and oxygen levels," Brazilian Journal of Chemical Engineering, vol. 22, no. 1, pp. 9-18, 2005.

[9] P. P. Polizelli, M. J. Tiera, and G. O. Bonilla-Rodriguez, "Effect of surfactants and polyethylene glycol on the activity and stability of a lipase from oilseeds of Pachira aquatica," Journal of the American Oil Chemists' Society, vol. 85, no. 8, pp. 749-753, 2008.

[10] M. Perle, S. Kimchie, and G. Shelef, "Some biochemical aspects of the anaerobic degradation of dairy wastewater," Water Research, vol. 29, no. 6, pp. 1549-1554, 1995.

[11] M. C. Cammarota and D. M. G. Freire, "A review on hydrolytic enzymes in the treatment of wastewater with high oil and grease content," Bioresource Technology, vol. 97, no. 17, pp. 2195-2210, 2006.

[12] A. B. G. Valladão, A. G. Torres, D. M. G. Freire, and M. C. Cammarota, "Profiles of fatty acids and triacylglycerols and their influence on the anaerobic biodegradability of effluents from poultry slaughterhouse," Bioresource Technology, vol. 102, no. 14, pp. 7043-7050, 2011.

[13] L. Masse, K. J. Kennedy, and S. Chou, "Testing of alkaline and enzymatic hydrolysis pretreatments for fat particles in slaughterhouse wastewater," Bioresource Technology, vol. 77, no. 2, pp. 145-155, 2001.

[14] L. Masse, D. I. Massé, and K. J. Kennedy, "Effect of hydrolysis pretreatment on fat degradation during anaerobic digestion of slaughterhouse wastewater," Process Biochemistry, vol. 38, no. 9, pp. 1365-1372, 2003.

[15] A. D’Annibale, G. G. Sermanni, F. Federici, and M. Petruccioli, "Olive-mill wastewaters: a promising substrate for microbial lipase production," Bioresource Technology, vol. 97, no. 15, pp. 1828-1833, 2006

[16] J. Jeganathan, G. Nakhla, and A. Bassi, "Hydrolytic pretreatment of oily wastewater by immobilized lipase," Journal of Hazardous Materials, vol. 145, no. 1-2, pp. 127-135, 2007.

[17] E. Rigo, R. E. Rigoni, P. Lodea et al., "Comparison of two lipases in the hydrolysis of oil and grease in wastewater of the swine meat industry," Industrial and Engineering Chemistry Research, vol. 47, no. 6, pp. 1760-1765, 2008.

[18] D. Alberton, D. A. Mitchell, J. Cordova, P. Peralta-Zamora, and N. Krieger, "Production of a fermented solid containing lipases of Rhizopus microsporus and its application in the prehydrolysis of a high-fat dairy wastewater," Food Technology and Biotechnology, vol. 48, no. 1, pp. 28-35, 2010.

[19] P. Rathi, R. K. Saxena, and R. Gupta, "A novel alkaline lipase from Burkholderia cepacia for detergent formulation," Process Biochemistry, vol. 37, no. 2, pp. 187-192, 2001.

[20] N. Saisubramanian, N. G. Edwinoliver, N. Nandakumar, N. R. Kamini, and R. Puvanakrishnan, "Efficacy of lipase from Aspergillus niger as an additive in detergent formulations: a statistical approach," Journal of Industrial Microbiology and Biotechnology, vol. 33, no. 8, pp. 669-676, 2006.

[21] E. Jurado, V. Bravo, G. Luzón et al., "Hard-surface cleaning using lipases: enzyme-surfactant interactions and washing tests," Journal of Surfactants and Detergents, vol. 10, no. 1, pp. 61-70, 2007. 
[22] C. Hemachander and R. Puvanakrishnan, "Lipase from Ralstonia pickettii as an additive in laundry detergent formulations," Process Biochemistry, vol. 35, no. 8, pp. 809-814, 2000.

[23] A. Rinzema, A. Alphenaar, and G. Lettinga, "Anaerobic digestion of long-chain fatty acids in UASB and expanded granular sludge bed reactors," Process Biochemistry, vol. 28, no. 8, pp. 527537, 1993.

[24] R. Boyer, Modern Experimental Biochemistry, Benjamin Cummings, San Francisco, Calif, USA, 2000.

[25] M. M. Bradford, "A rapid and sensitive method for the quantitation of microgram quantities of protein utilizing the principle of protein dye binding," Analytical Biochemistry, vol. 72, no. 1-2, pp. 248-254, 1976.

[26] J. H. Zar, Biostatistical Analysis, Prentice Hall, Englewood Cliffs, NJ, USA, 4th edition, 1999.

[27] M. Ayres, M. Ayres Jr., D. I. Ayres, and A. S. Santos, BioEstat 4.0: Aplicações estatísticas nas áreas das ciências biológicas e médicas, Sociedade Civil Mamirauá, MCt e Imprensa Oficial do Estado do Pará, Belém, Brazil, 2005.

[28] D. Goswami, S. De, and J. K. Basu, "Effects of process variables and additives on mustard oil hydrolysis by porcine pancreas lipase," Brazilian Journal of Chemical Engineering, vol. 29, pp. 449-460, 2012.

[29] J. Christner, "The use of lipases in the beamhouse processes," The Journal of the American Leather Chemists Association, vol. 87, pp. 128-139, 1992.

[30] R. D. Abigor, P. O. Uadia, T. A. Foglia, M. J. Haas, K. Scott, and B. J. Savary, "Partial purification and properties of lipase from germinating seeds of Jatropha Curcas L," Journal of the American Oil Chemists' Society, vol. 79, no. 11, pp. 1123-1126, 2002.

[31] B. O. Ejedegba, E. C. Onyeneke, and P. O. Oviasogie, "Characteristics of lipase isolated from coconut (Cocos nucifera linn) seed under different nutrient treatments," African Journal of Biotechnology, vol. 6, no. 6, pp. 723-727, 2007.

[32] P. J. Eastmond, "Cloning and characterization of the acid lipase from Castor beans," Journal of Biological Chemistry, vol. 279, no. 44, pp. 45540-45545, 2004.

[33] N. K. Sana, I. Hossin, E. M. Haque, and R. K. Shaha, "Identification, purification and characterization of lipase from germinating oil seeds (Brassica napus L.)," Pakistan Journal of Biological Sciences, vol. 7, no. 2, pp. 246-252, 2004.

[34] I. B.-B. Romdhane, A. Fendri, Y. Gargouri, A. Gargouri, and H. Belghith, "A novel thermoactive and alkaline lipase from Talaromyces thermophilus fungus for use in laundry detergents," Biochemical Engineering Journal, vol. 53, no. 1, pp. 112-120, 2010.

[35] V. Delorme, R. Dhouib, S. Canaan, F. Fotiadu, F. Carrière, and J.-F. Cavalier, "Effects of surfactants on lipase structure, activity, and inhibition," Pharmaceutical Research, vol. 28, no. 8, pp. 18311842, 2011.

[36] H. Andree, W. R. Muller, and R. D. Schmid, "Lipases as detergent components," Journal of Applied Biochemistry, vol. 2, pp. 218-219, 1980.

[37] N. G. Wakelin and C. F. Forster, "An investigation into microbial removal of fats, oils and greases," Bioresource Technology, vol. 59, no. 1, pp. 37-43, 1997.

[38] V. del Nery, M. H. Z. Damianovic, and F. G. Barros, “The use of upflow anaerobic sludge blanket reactors in the treatment of poultry slaughterhouse wastewater," Water Science and Technology, vol. 44, no. 4, pp. 83-88, 2001.

[39] F. D. Grindstone, J. L. Hardwood, and F. B. Padley, The Lipid Handbook, Chapman and Hall, London, UK, 1986. 

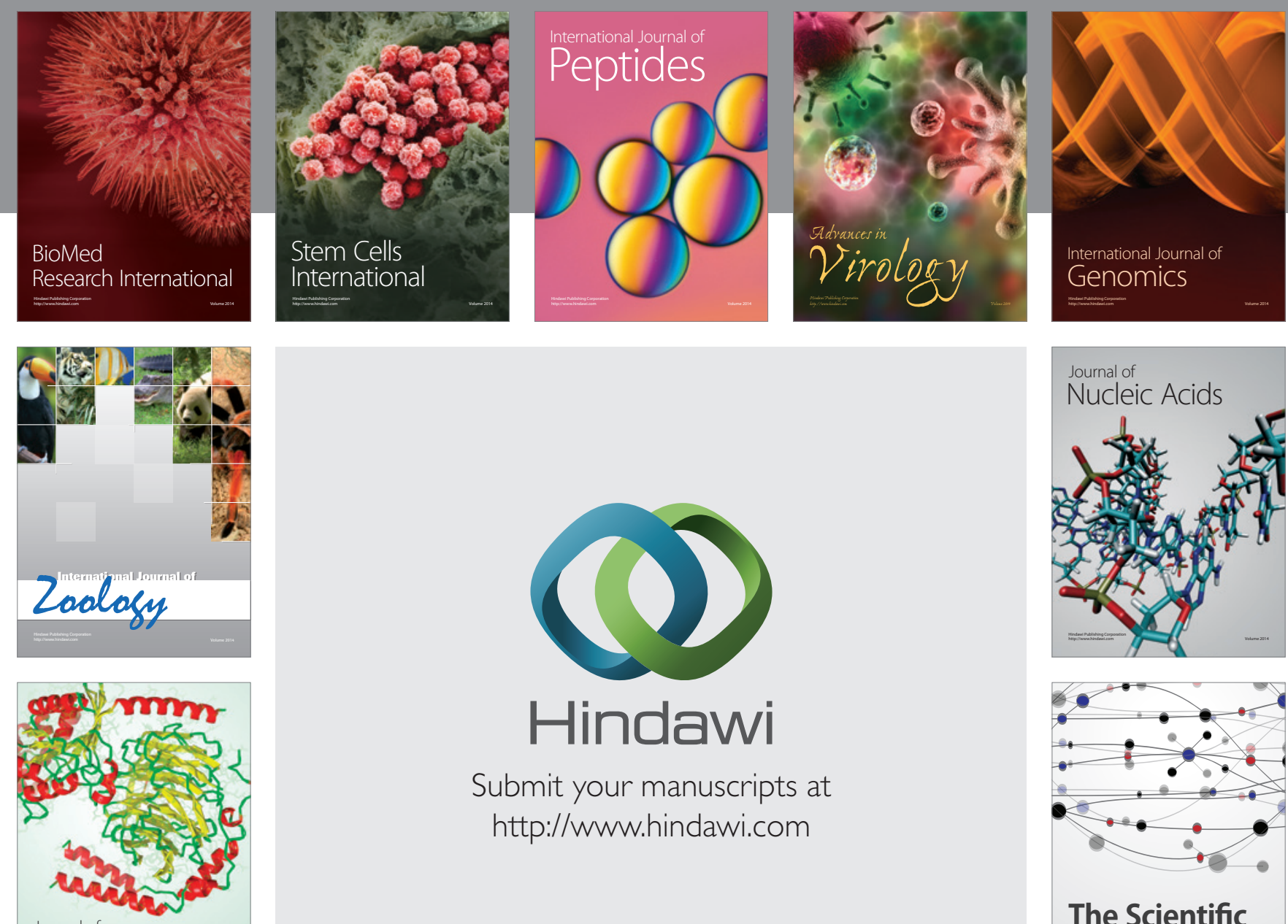

Submit your manuscripts at

http://www.hindawi.com

Journal of
Signal Transduction
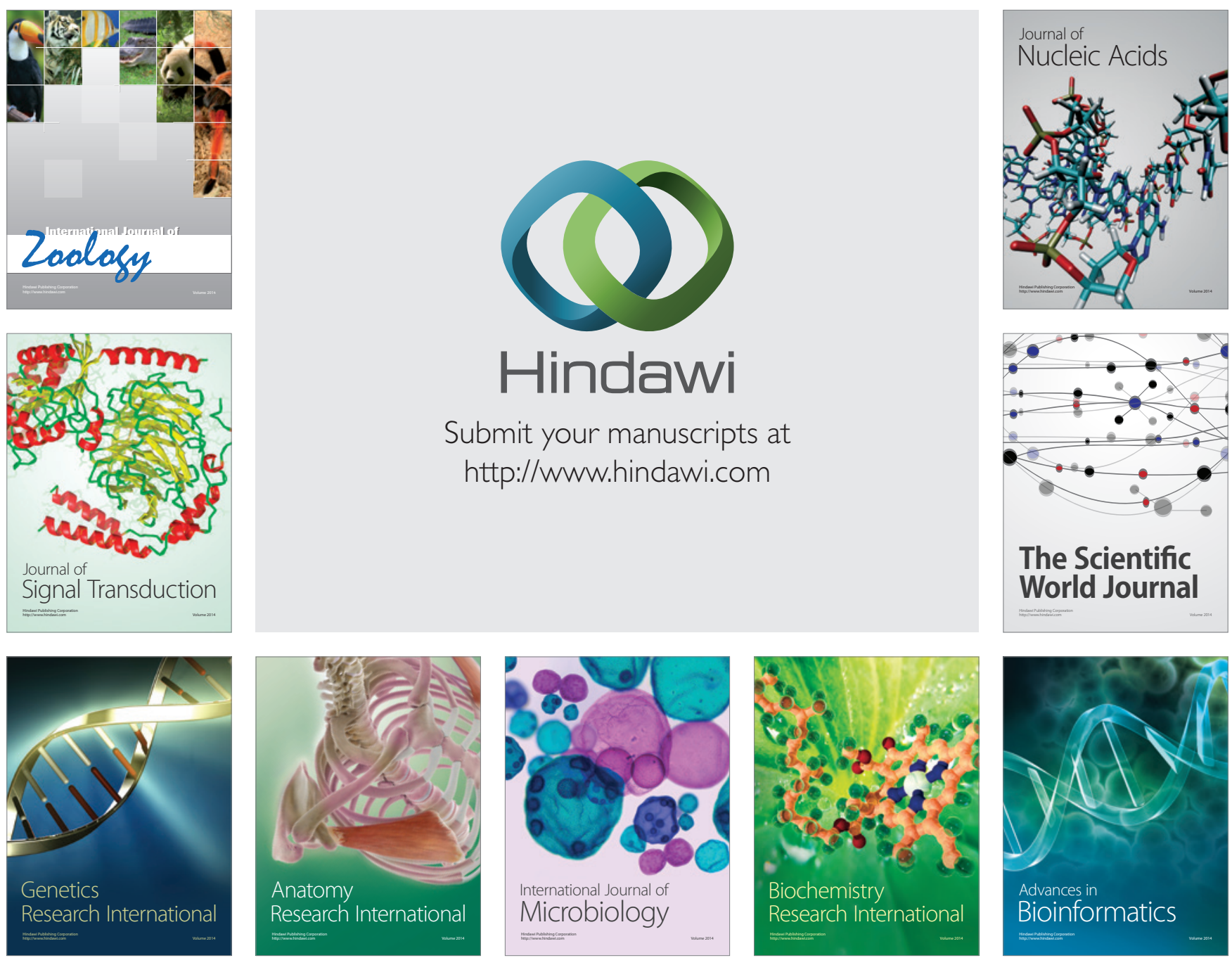

The Scientific World Journal
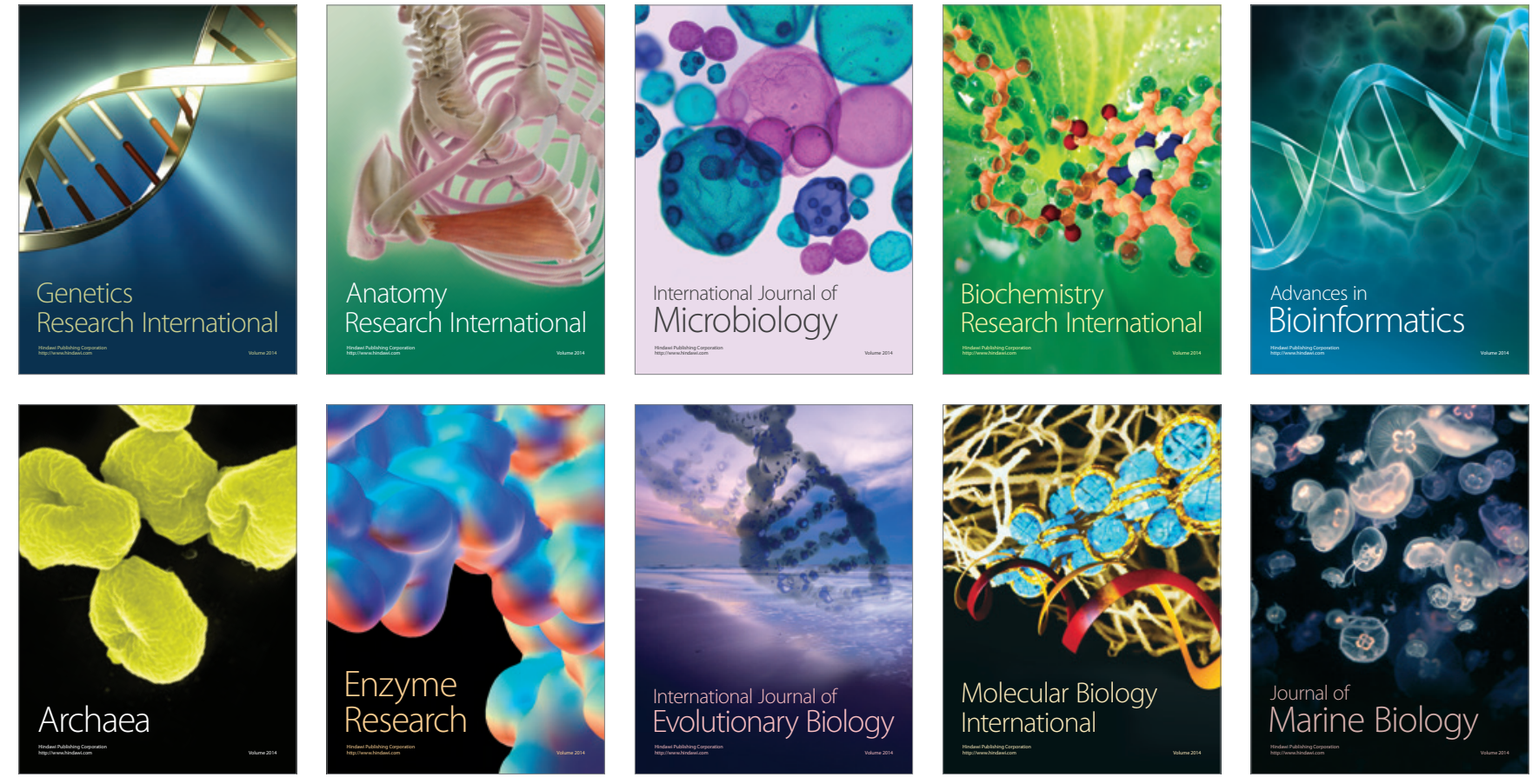